\title{
Technical Note: Measurement of Ferritin in Bovine Milk and Its Clinical Significance
}

\author{
K. Orino, ${ }^{\star 1}$ S. Watanabe,${ }^{*}$ H. Ohtsuka,† M. Kohiruimaki, $¥$ and K. Watanabe* \\ *Laboratories of Biochemistry and \\ †Large Animal Internal Medicine, School of Veterinary Medicine and Animal Sciences, Kitasato University, Aomori 034-8628, Japan \\ ¥Kohiruimaki Animal Medical Service, Tohoku, Aomori 039-2683, Japan
}

\section{ABSTRACT}

A quantitative ELISA was developed for bovine milk ferritin with an assay limit of $0.16 \mathrm{ng} / \mathrm{mL}$ of bovine spleen ferritin. Ferritin-binding activity was detected in bovine milk samples, and this binding activity was inhibited by increasing ionic strength with the addition of $0.5 \mathrm{M}\left(\mathrm{NH}_{4}\right)_{2} \mathrm{SO}_{4}$. Heat treatment $\left(60^{\circ} \mathrm{C}, 20 \mathrm{~min}\right)$ of bovine milk in the presence of $0.5 \mathrm{M}\left(\mathrm{NH}_{4}\right)_{2} \mathrm{SO}_{4}$ resulted in a 15 to $58 \%$ increase in ferritin concentrations compared with untreated samples. Although the recovery of bovine spleen ferritin added to milk was still low (55 to $90 \%$ ), even in the presence of increased ionic strength with $0.5 M\left(\mathrm{NH}_{4}\right)_{2} \mathrm{SO}_{4}$, recovery was improved by heat treatment at $60^{\circ} \mathrm{C}$ for $20 \mathrm{~min}(92$ to $95 \%)$. Milk ferritin concentrations in 30 milk samples from quarters of 25 cows with mastitis (mean $\pm \mathrm{SE}: 134.2 \pm 28.7 \mathrm{ng} / \mathrm{mL}$ ) were significantly higher than those in 17 quarter milk samples from 17 noninfected lactating cows $(7.2 \pm 1.2$ $\mathrm{ng} / \mathrm{mL}$ ), suggesting that bovine milk contains putative ferritin-binding proteins that inhibit immunoassay for milk ferritin and that bovine milk ferritin is an indicator of IMI.

Key words: ferritin, milk, cow, mastitis

Ferritin, an iron-binding protein, is a ubiquitous protein present in all living organisms, from microorganisms to mammals (Andrews et al., 1992). In mammals, ferritin is present in relatively low concentrations $(<1$ $\mu \mathrm{g} / \mathrm{mL}$ ) in the circulation as well as in tissues. Serum ferritin levels correlate with body iron stores and are useful for the diagnosis of iron deficiency or overload (Miyata and Furugouri, 1987). Serum ferritin is a marker for malignant and inflammatory diseases based on hyperferritinemia observed in infectious disease, leukemia, and solid tumors (Jones et al., 1980; Lorier et al., 1985). In humans, ferritin is also present in extracellular fluids, such as milk (Arosio et al., 1986) and synovial fluids (Ohta and Katsuki, 1998). Ferritin con-

Received February 21, 2006.

Accepted May 2, 2006.

${ }^{1}$ Corresponding author: orino@vmas.kitasato-u.ac.jp centrations in colostrum and lactating milk samples are remarkably higher than in serum, although their secretory mechanisms have not been clarified (Arosio et al., 1986). We examined the presence of ferritin-binding proteins and the inhibitory effects of milk on a ferritin immunoassay, and developed an ELISA method to measure ferritin in bovine milk. This report evaluates the clinical significance of measuring milk ferritin in cows with mastitis.

After milking, 3 to 6 squirts of milk were collected from all quarters of Holstein-Friesian dairy cows. Milk samples were classified by the California Mastitis Test to detect mastitis. A total of 17 quarters from 17 noninfected cows and 30 California Mastitis Test-positive quarters from 25 lactating cows with subclinical mastitis were used. The SCC was determined with the MilkoScan 4000 (Foss Electric, Hillerød, Denmark). Bovine spleen ferritin monomers were purified from bovine spleen as described previously (Kakuta et al., 1997). Protein concentration was measured according to the method of Lowry et al. (1951) using BSA (Boehringer Mannheim, Mannheim, Germany) as the standard. Antibodies to bovine spleen ferritin were purified from rabbit antisera by affinity chromatography as described previously (Watanabe et al., 1998). Purified rabbit antibovine spleen ferritin polyclonal antibody was biotinylated according to the manufacturer's instructions with soluble sulfosuccinimidobiotin (Pierce, Rockford, IL) with a molar ratio of sulfosuccinimidobiotin to antibody of $20: 1$.

Sandwich ELISA for bovine milk was performed as previously described (Watanabe et al., 1998), with the exceptions that sheep antibiotin antibody (Bethyl Laboratories, Inc., Montgomery, TX) and alkaline phosphatase (ALP)-labeled goat antisheep IgG antibody (Chemicon International, Inc., Temecula, CA) were used in place of streptavidin and biotin-labeled ALP for lower cost. Briefly, $100 \mu \mathrm{L}$ of antibovine spleen ferritin antibody $(200 \mathrm{ng} / \mathrm{mL})$ in PBS ( $150 \mathrm{~m} M \mathrm{NaCl}, 20 \mathrm{~m} M$ sodium phosphate, $\mathrm{pH}$ 7.2) was added to the wells of an Immuno Plate Maxisorp microtiter plate (Nunc, Roskilde, Denmark). After washing with PBS containing $0.5 \%$ Tween 20 (PBST), $100-\mu \mathrm{L}$ aliquots of bovine spleen ferritin 
Table 1. The effect of $0.5 \mathrm{M}\left(\mathrm{NH}_{4}\right)_{2} \mathrm{SO}_{4}$ and heat treatment on recoveries of bovine spleen ferritin added to bovine milk $^{1}$

\begin{tabular}{|c|c|c|c|c|c|}
\hline \multirow[b]{2}{*}{$\begin{array}{l}\text { Sample } \\
\text { no. }\end{array}$} & \multirow[b]{2}{*}{$\begin{array}{l}\text { Added } \\
\text { ferritin, } \\
\text { ng/mL }\end{array}$} & \multicolumn{2}{|c|}{ Untreated serum } & \multicolumn{2}{|c|}{ Heat-treated serum } \\
\hline & & $\begin{array}{l}\text { Recovered } \\
\text { ferritin, } \\
\text { ng/mL }\end{array}$ & $\begin{array}{l}\text { Recovery, } \\
\%\end{array}$ & $\begin{array}{l}\text { Recovered } \\
\text { ferritin, } \\
\text { ng/mL }\end{array}$ & $\begin{array}{l}\text { Recovery, } \\
\%\end{array}$ \\
\hline \multirow[t]{2}{*}{1} & 0 & 1.17 & & 1.76 & \\
\hline & 1.25 & 2.29 & 90 & 2.94 & 94 \\
\hline \multirow[t]{2}{*}{2} & 0 & 0.29 & & 0.46 & \\
\hline & 1.25 & 0.98 & 55 & 1.61 & 92 \\
\hline \multirow[t]{2}{*}{3} & 0 & 0.30 & & 0.58 & \\
\hline & 1.25 & 1.21 & 73 & 1.77 & 95 \\
\hline
\end{tabular}

${ }^{1}$ Bovine milk was diluted 6 -fold and was then heat-treated at $60^{\circ} \mathrm{C}$ for $20 \mathrm{~min}$, and the ferritin concentration was determined by sandwich ELISA.

standards or milk samples in ELISA buffer (PBS containing $0.1 \%$ Tween 20 and $0.1 \%$ gelatin, $\mathrm{pH} 7.2)$, both containing $0.5 \mathrm{M}\left(\mathrm{NH}_{4}\right)_{2} \mathrm{SO}_{4}$, were added to each well of the plate, and the plate was incubated at $37^{\circ} \mathrm{C}$ for 2 h. After washing with PBST, $100-\mu \mathrm{L}$ aliquots of 250 $\mathrm{ng} / \mathrm{mL}$ biotinylated antiferritin antibody were added to the wells of the plate, and the plate was incubated at $37^{\circ} \mathrm{C}$ for $2 \mathrm{~h}$. After washing, $100 \mu \mathrm{L}$ of sheep antibiotin antibody diluted 4,000-fold with ELISA buffer was added to each well of the plate, and the plate was incubated at $37^{\circ} \mathrm{C}$ for $1.5 \mathrm{~h}$. After washing, $100 \mu \mathrm{L}$ of ALPlabeled goat antisheep IgG antibody diluted 10,000-fold with ELISA buffer was added to each well of the plate, and the plate was incubated at $37^{\circ} \mathrm{C}$ for $1.5 \mathrm{~h}$. After washing, the enzyme reaction was carried out using $p$ nitrophenyl phosphate as previously described (Orino et al., 1993a). To produce conditions of increased ionic strength, milk samples were diluted with ELISA buffer and adjusted to achieve a final concentration of $0.5 \mathrm{M}$ $\left(\mathrm{NH}_{4}\right)_{2} \mathrm{SO}_{4}$. The samples were then subjected to heat treatment by heating at $60^{\circ} \mathrm{C}$ for $20 \mathrm{~min}$, and the ferritin concentration was determined by sandwich ELISA.

Aliquots $(100 \mu \mathrm{L})$ of milk samples diluted 100-fold with PBS were added to the wells of a microtiter plate and incubated overnight at $4^{\circ} \mathrm{C}$. After washing with PBST, $100 \mu \mathrm{L}$ of bovine spleen ferritin $(5 \mu \mathrm{g} / \mathrm{mL})$ in ELISA buffer was tested with modifications to ionic strength [presence or absence of $0.5 \mathrm{M}\left(\mathrm{NH}_{4}\right)_{2} \mathrm{SO}_{4}$ ], and the plate was incubated at $37^{\circ} \mathrm{C}$ for $2 \mathrm{~h}$. After washing, $100-\mu \mathrm{L}$ aliquots of ALP-labeled antibovine spleen ferritin antibody (250 ng/mL; Watanabe et al., 1998) in ELISA buffer were added. After washing, the enzyme reaction was carried out using $p$-nitrophenyl phosphate as previously described (Orino et al., 1993a). The Mann-Whitney $U$-test was performed for statistical analysis of the data, and the statistical difference was defined at $P<0.01$.

Ferritin-binding activity was detected in bovine milk samples, and this activity $\left(\mathrm{A}_{405 \mathrm{~nm}}=0.56 \pm 0.05, \mathrm{SE}\right)$ was inhibited by increased ionic strength $(0.10 \pm 0.004)$. The ELISA standard curve had an assay sensitivity limit of $0.16 \mathrm{ng} / \mathrm{mL}$ for bovine spleen ferritin. The recovery of bovine spleen ferritin added to bovine milk samples was low (55 to 92\%), even after increasing the ionic strength (Table 1). Because bovine ferritin is a heatstable protein (Kakuta et al., 1997), we tried to denature heat-labile putative ferritin-binding proteins by heat treatment. The recovery improved (92 to $95 \%$ ) by increasing ionic strength and heating, indicating that both treatments eliminated inhibitory effects of the putative ferritin-binding proteins completely. However, heat treatment at $60^{\circ} \mathrm{C}$ for 20 min yielded the highest recoveries of ferritin added to milk samples compared with other heat treatments $\left(70^{\circ} \mathrm{C}\right.$ or $80^{\circ} \mathrm{C}$; data not shown). Following heat treatment, measured milk ferritin concentrations increased by 18 to $55 \%$ compared with untreated milk. Assays with diluted milk samples from 2 normal lactating cows showed that milk ferritin concentrations correlated with milk dilution in a strong linear relationship (Figure 1). Based on these results, the ELISA system developed could be used to measure ferritin concentrations greater than $1.0 \mathrm{ng} / \mathrm{mL}$ in at least 6-fold diluted milk. The intraassay coefficient of variation of 4 determinations on a single milk sample was $5.1 \%$, and the interassay coefficient of variation of 4 measurements on a single milk sample was $5.2 \%$.

Milk ferritin concentrations of normal cows were 7.2 $\pm 1.2 \mathrm{ng} / \mathrm{mL}$ (range 2.0 to $21.8 \mathrm{ng} / \mathrm{mL}$ ) and were lower $(P<0.01)$ than those of cows with IMI $(134.2 \pm 28.7 \mathrm{ng} /$ $\mathrm{mL}$; range 8.9 to $501.6 \mathrm{ng} / \mathrm{mL}$; Figure 2). However, there was no correlation between milk ferritin concentrations and SCC in cows with mastitis $(r=0.076)$.

Inhibitory effects of horse and bovine sera on ferritin immunoassays have been reported (Orino et al., 1993a,b, 2004). We hypothesize that putative ferritinbinding proteins conceal the epitope of the ferritin molecule to antiferritin antibodies used in the immunoassay. These inhibitory effects were eliminated by heat treat- 


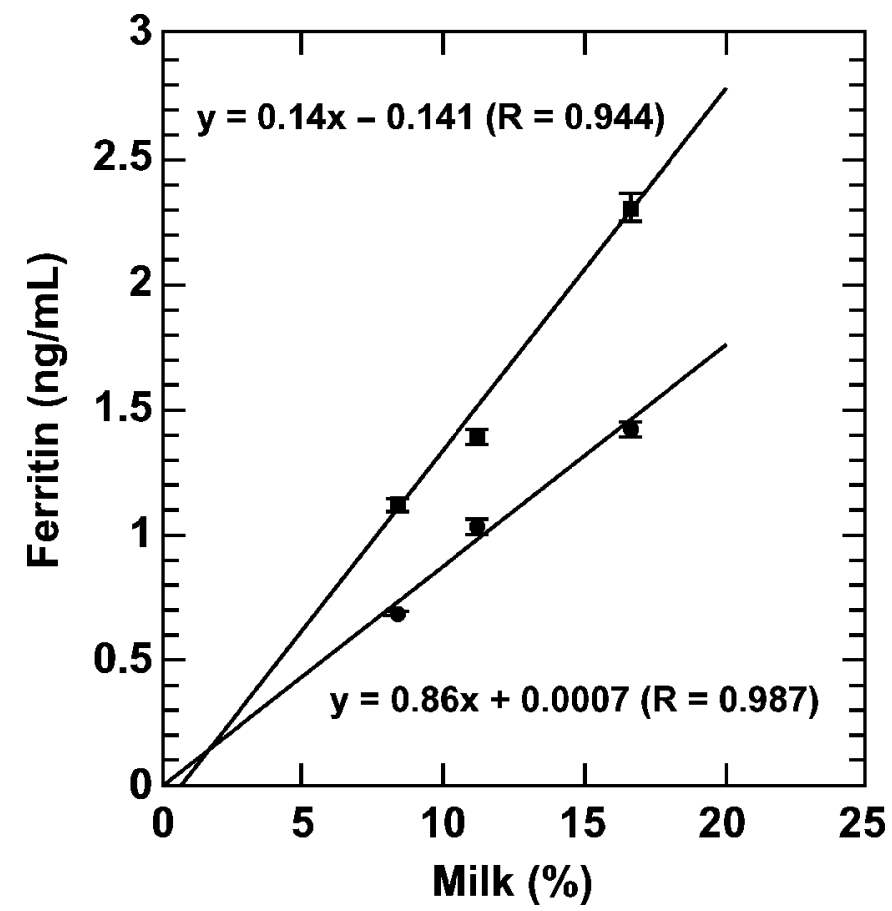

Figure 1. Effect of milk dilution on ELISA determination of milk ferritin concentrations. Milk samples were diluted 6-, 9-, or 12-fold, heat-treated, and assayed for ferritin by sandwich ELISA. Bars represent mean $\pm \mathrm{SE}$ of quadruplicate determinations.

ment $\left(75^{\circ} \mathrm{C}, 20 \mathrm{~min}\right)$ or by an increase in the ionic strength of the serum, suggesting that these treatments dissociate putative ferritin-binding proteins from ferritin molecules (Orino et al., 1993a,b, 2004). Bovine milk has native ferritin-binding activity, and although ferritin-binding activity was inhibited by increased ionic treatment, the recovery of bovine spleen ferritin added to milk samples was low (55 to $92 \%$ ) under conditions of increased ionic strength. In addition, the combination of both heat treatment and increased ionic strength improved the recovery (92 to 95\%) in bovine milk samples. Heat treatment at $60^{\circ} \mathrm{C}$ for 20 min resulted in highest recoveries of ferritin added to milk samples compared with other heat treatments $\left(70\right.$ to $\left.80^{\circ} \mathrm{C}\right)$, suggesting that bovine milk ferritin is less heat stable than tissue ferritin and that bovine milk ferritin is aggregated with denatured proteins, including ferritin-binding proteins. These results suggest that bovine milk contains heat-labile components that both inhibit immunoassay of ferritin and lose ferritin-binding activity with increased ionic strength treatment because of their reduced affinity to ferritin.

Ferritin-binding proteins are involved in rapid sequestration of circulating ferritin by forming complexes (Watanabe et al., 2000; Orino et al., 2004). In mammals, no milk ferritin-binding proteins have been identified

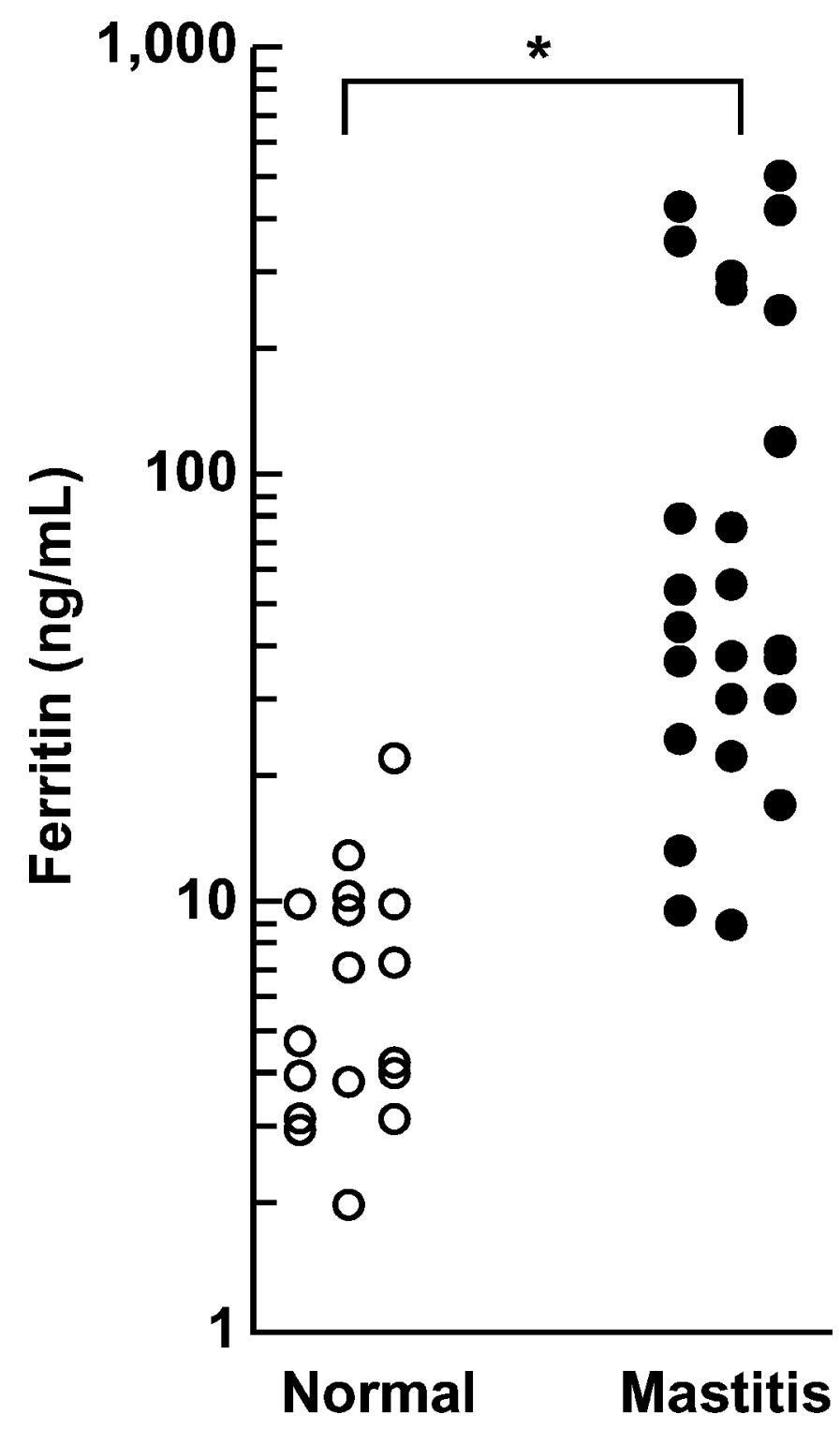

Figure 2. Milk ferritin concentrations in normal lactating cows (open circles) and cows with mastitis (solid circles). *Significant difference compared with normal lactating cows $(P<0.01)$.

to date. Although a human milk ferritin immunoassay has been developed (Arosio et al., 1986), the presence of ferritin-binding proteins or the effect of milk on ferritin immunoassays remains to be clarified.

Although the bovine milk ferritin concentration did not correlate with SCC, milk ferritin levels increased in cows with mastitis, suggesting that the increase in milk ferritin was due to the release of ferritin into milk from the death of epithelial cells (Diarra et al., 2002). The lactoferrin concentrations of cows with mastitis increase and lactoferrin plays a role in inhibiting bacterial growth by sequestering iron (Hagiwara et al., 2003). 
Human milk ferritin contains little iron (Arosio et al., 1986), suggesting that milk ferritin could enhance antimicrobial resistance in host defense systems as ferritin removes iron for bacterial growth (Lipiński et al., 1991). Although a cross-reaction between the antiferritin antibody and microbial ferritin has not been examined, high ferritin levels in the milk of cows with IMI are unlikely to be derived from microbial ferritin because of the low AA sequence homologies (20\%) between mammalian ferritins and microbial ferritins (Andrews et al., 1992). Some sera obtained showed higher ferritin concentrations than those in normal cows (data not shown). Serum ferritin determination, as well as bovine milk ferritin determination, may be useful for the diagnosis and prognosis of IMI in cows.

\section{REFERENCES}

Andrews, S. C., P. Arosio, W. Bottke, J.-F. Briat, M. von Darl, P. M. Harrison, J.-P. Laulhère, S. Levi, S. Lobreaux, and S. J. Yewdall. 1992. Structure, function, and evolution of ferritins. J. Inorg. Biochem. 47:161-174.

Arosio, P., A. Ponzone, R. Ferrero, I. Renoldi, and S. Levi. 1986. Characteristics of ferritins in human milk secretions: Similarities to serum and tissue isoferritins. Clin. Chim. Acta 161:201-208.

Diarra, M. S., D. Petitclerc, and P. Lacasse. 2002. Response of Staphylococcus aureus isolates from bovine mastitis to exogenous iron sources. J. Dairy Sci. 82:2141-2148.

Hagiwara, S., K. Kawai, A. Anri, and H. Nagahata. 2003. Lactoferrin concentrations in milk from normal and subclinical mastitic cows. J. Vet. Med. Sci. 65:319-323.
Jones, B. M., M. Worwood, and A. Jacobs. 1980. Serum ferritin in patients with cancer: Determination with antibodies to HeLa cell and spleen ferritin. Clin. Chim. Acta 106:203-214.

Kakuta, K., K. Orino, S. Yamamoto, and K. Watanabe. 1997. High levels of ferritin and its iron in fetal bovine serum. Comp. Biochem. Physiol. 118A:165-169.

Lipiński, P., Z. Jarzabek, S. Broniek, and T. Zagulski. 1991. Protective effect of tissue ferritin in experimental Escherichia coli infection of mice in vivo. Int. J. Exp. Pathol. 72:623-630.

Lorier, M. A., J. L. Herron, and R. W. Carrel. 1985. Detecting iron deficiency by serum tests. Clin. Chem. 31:337-338.

Lowry, O. H., N. J. Rosebrough, A. L. Farr, and R. J. Randall. 1951. Protein measurement with the Folin phenol reagent. J. Biol. Chem. 193:265-275.

Miyata, Y., and K. Furugouri. 1987. The relationship between serum ferritin concentration and tissue non-heme iron or tissue ferritin in dairy cattle. Jpn. J. Vet. Sci. 49:1157-1159.

Ota, T., and I. Katsuki. 1998. Ferritin subunits in sera and synovical fluids from patients with rheumatoid arthritis. J. Rheumatol. 25:2315-2318.

Orino, K., T. Ishiji, S. Yamamoto, and K. Watanabe. 2004. Characterization of bovine serum ferritin-binding proteins. Comp. Biochem. Physiol. 137A:375-381.

Orino, K., M. Saji, Y. Ozaki, T. Ohya, S. Yamamoto, and K. Watanabe. 1993a. Inhibitory effect of horse serum on immunoassay of horse ferritin. J. Vet. Med. Sci. 55:45-49.

Orino, K., S. Yamamoto, and K. Watanabe. 1993b. Fibrinogen as a ferritin-binding protein in horse plasma. J. Vet. Med. Sci. 55:785-787.

Watanabe, K., K. Hayashi, T. Miyamoto, M. Tanaka, S. Okano, and S. Yamamoto. 2000. Characterization of ferritin and ferritin-binding proteins in canine serum. Biometals 13:57-63.

Watanabe, K., M. Ozawa, H. Ochiai, H. Kamohara, N. Iijima, H. Negita, K. Orino, and S. Yamamoto. 1998. Change in iron and ferritin in anemic calves infected with Theileria sergenti. J. Vet. Med. Sci. 60:943-947. 